\title{
Associations of 25-hydroxyvitamin D with fasting glucose, fasting insulin, dementia and depression in European elderly: the SENECA study
}

\author{
Elske M. Brouwer-Brolsma $\cdot$ Edith J. M. Feskens • \\ Wilma T. Steegenga $\cdot$ Lisette C. P. G. M. de Groot
}

Received: 26 January 2012/ Accepted: 4 June 2012/Published online: 23 June 2012

(C) The Author(s) 2012. This article is published with open access at Springerlink.com

\begin{abstract}
Purpose The classical consequence of vitamin D deficiency is osteomalacia, but recent insights into the function of vitamin D suggest that it may play a role in other body systems as well. The objective of this study was to examine the association between 25-hydroxyvitamin D $(25(\mathrm{OH}) \mathrm{D})$ and markers of glucose metabolism $(n=593)$, global cognitive functioning $(n=116)$ and depression $(n=118)$ in European elderly participating in the SENECA study. Moreover, we wanted to explore whether the observed associations of $25(\mathrm{OH}) \mathrm{D}$ with depression and global cognitive performance were mediated by fasting plasma glucose (FPG) levels.

Methods Cross-sectional associations between 25(OH)D and FPG, fasting plasma insulin (FPI) and homeostatic model assessment-insulin resistance (HOMA-IR), a marker of insulin resistance, were estimated from multiple regression analyses. Associations of 25(OH)D with global cognitive functioning (Mini Mental State Examination) and depression (Geriatric Depression Scale) were examined using Poisson regression.

Results An inverse association was observed between $25(\mathrm{OH}) \mathrm{D}$ and FPG $(\beta-0.001)$, indicating a $1 \%$ decrease in FPG per $10 \mathrm{nmol} / \mathrm{L}$ increase in $25(\mathrm{OH}) \mathrm{D}$, but after full adjustment for demographic factors, lifestyle factors and calcium intake, this association was not statistically significant $(P=0.07)$. Although participants with intermediate and high serum 25(OH)D levels showed a tendency towards a lower depression score after adjustment for
\end{abstract}

E. M. Brouwer-Brolsma ( $₫)$ · E. J. M. Feskens .

W. T. Steegenga - L. C. P. G. M. de Groot

Division of Human Nutrition, Wageningen University,

PO Box 8129, 6700 EV Wageningen, The Netherlands

e-mail: Elske.Brouwer@wur.nl demographic and lifestyle factors, RR and $95 \%$ CI: 0.73 (0.51-1.04) and $0.76(0.52-1.11)$, respectively, these findings were not statistically significant.

Conclusion An inverse association of $25(\mathrm{OH}) \mathrm{D}$ with depression and FPG was observed, but this association was not statistically significant. There was no association between 25(OH)D with FPI and HOMA-IR or with global cognitive functioning. More studies are needed to further explore the possible role of vitamin D in the various body systems.

Keywords Vitamin D - Type 2 diabetes mellitus · Insulin sensitivity $\cdot$ Dementia $\cdot$ Depression $\cdot$ Cross-sectional

\section{Introduction}

Worldwide, approximately 347 million people are affected by diabetes [1], mainly type 2 diabetes. Recent epidemiological studies suggest that diabetic patients are at increased risk of dementia [2] and depression [3]. The question whether the observed associations between these three ageing-related diseases are the result of shared risk factors or specific biological mechanisms, however, remains to be solved. Vitamin D deficiency is one of the postulated links [4-8].

Hypovitaminosis D is commonly observed in the elderly population. A restricted ultraviolet light exposure, low vitamin D intake and a decreased skin synthesis capacity may be related to the development of vitamin D deficiency in ageing populations. In NHANES III, Martins and colleagues observed lower $25(\mathrm{OH}) \mathrm{D}$ levels in women, persons $\geq 60$ years and obese and diabetic participants [9]. In 1984, a study among middle-aged and elderly English men and women showed that post-prandial glucose levels were 
highest during the winter period [10]. Since then, evidence supporting a role for vitamin D in glucose metabolism expanded, including among others the identification of vitamin $\mathrm{D}$ receptors in the human pancreatic $\beta$-cell [11], the expression of 1 - $\alpha$-hydroxylase enzyme in the $\beta$-cell [12] and stimulation of the expression of insulin receptors by vitamin $D$ in vitro [13]. The presence of $1-\alpha-$ hydroxylase in cerebrospinal fluid and the existence of vitamin D receptors (VDRs) on various brain structures [14] support the hypothesis that vitamin D is involved in mental health.

However, while animal experiments point towards a protective effect of vitamin $\mathrm{D}$ with regard to the development of several age-related diseases, population-based studies have not yet provided conclusive evidence for the association with diabetes [4, 15], cognitive functioning [16-24] and depression [6-8, 25-28]. Therefore, our objective in this European multicentre cohort study was to examine $25(\mathrm{OH}) \mathrm{D}$ and the association with markers of glucose metabolism, cognitive functioning and depression in elderly men and women.

\section{Methods}

\section{Subjects}

The study is conducted using baseline data collected from European elderly participating in the SENECA study; Survey in Europe on Nutrition and the Elderly, a Concerted Action [29]. Men and women aged 70-75 years who were living in pre selected towns across Europe were invited for participation in the study. Towns were selected based upon their representativeness of the population and socio-economic structure for the whole country. Psycho-geriatric patients living in nursing homes, persons who were not fluent in the country's language or not able to independently answer questions were excluded from participation. The total SENECA population comprised 2,586 participants. Markers of glucose metabolism and serum 25(OH)D levels were measured in 1989 and available for 1,554 and 860 participants, respectively. Of 593 participants, both $25(\mathrm{OH}) \mathrm{D}$ and markers of glucose metabolism were measured. Data on cognitive functioning and depression were obtained in 1993 and available for 443 and 482 participants, of whom serum $25(\mathrm{OH}) \mathrm{D}$ levels were measured in 116 and 118 participants, respectively. Measurements of serum $25(\mathrm{OH}) \mathrm{D}$, markers of glucose metabolism and mental health were available of 98 (GDS) and 94 (MMSE) participants (Fig. 1). Included in the analyses were participants from: Belgium: Hamme; Denmark: Roskilde; France: Strassbourg and Valence; Hungary: Monor; the Netherlands: Culemborg; Norway: Elverum; Switzerland:
Yverdon, Burgdorf, and Bellinzona; Greece: Athens and Iraklion; Portugal: Lisbon; Spain: Madrid.

\section{Mental status}

Global cognitive functioning was assessed using the mini mental state examination (MMSE). The variable for analyses was defined as the maximum MMSE score minus the MMSE score of the participant, reflecting the number of erroneous answers. Mitchell et al. [30] recently reviewed the accuracy of the MMSE and showed a $85.1 \%$ sensitivity and a $85.5 \%$ specificity in non-clinical community settings. The 15-item geriatric depression scale (GDS) was used as a screenings tool for depression. Validation with the diagnostic and statistical manual of mental disorders (DSM-IV) revealed that $97.0 \%$ of the persons with depression (sensitivity) and $54.8 \%$ persons without depression (specificity) were correctly classified [31].

\section{Biochemical analyses}

Blood samples were taken between 7.30 and 9.30 AM while the participant was in a fasting state. Fasting blood samples $(25 \mathrm{~mL})$ were collected and $10 \mathrm{~mL}$ was transferred to another tube for serum separation. A portion $(0-5 \mathrm{~mL})$ of each serum sample was stored at $-80{ }^{\circ} \mathrm{C}$ for 25(OH)D determination. All blood samples were sent on dry ice to the coordinating centre in Wageningen, the Netherlands, and stored at $-80{ }^{\circ} \mathrm{C}$. Serum $25(\mathrm{OH}) \mathrm{D}$ values were analysed by competitive protein-binding assay (coefficients of variation: within-assay 4-7\%, betweenassay 7-10 \%) at the TNO Nutrition and Food Research Institute, Zeist, the Netherlands. As 25(OH)D concentrations may fluctuate seasonally, $25(\mathrm{OH}) \mathrm{D}$ was only determined in blood samples collected between January and March 1989. Plasma glucose concentration was measured by the hexokinase method using the Hitachi 911 autoanalyser. Plasma insulin concentration was measured by using enzyme immunoassay (Boehringer-Mannheim, Mannheim, Germany), and insulin resistance was calculated using homeostatic model assessment-insulin resistance (HOMA-IR) from glucose and insulin concentrations [32].

\section{Covariates}

Information on education level (illiterate, primary, secondary or higher education), smoking status (non-smokers, former smokers or current smokers) and presence of chronic disease (including among others stroke and hypertension) was collected using questionnaires. The Voorrips questionnaire, designed to assess physical activity level in elderly people, was used to obtain information on 
Fig. 1 Flow diagram describing the population used in the analyses

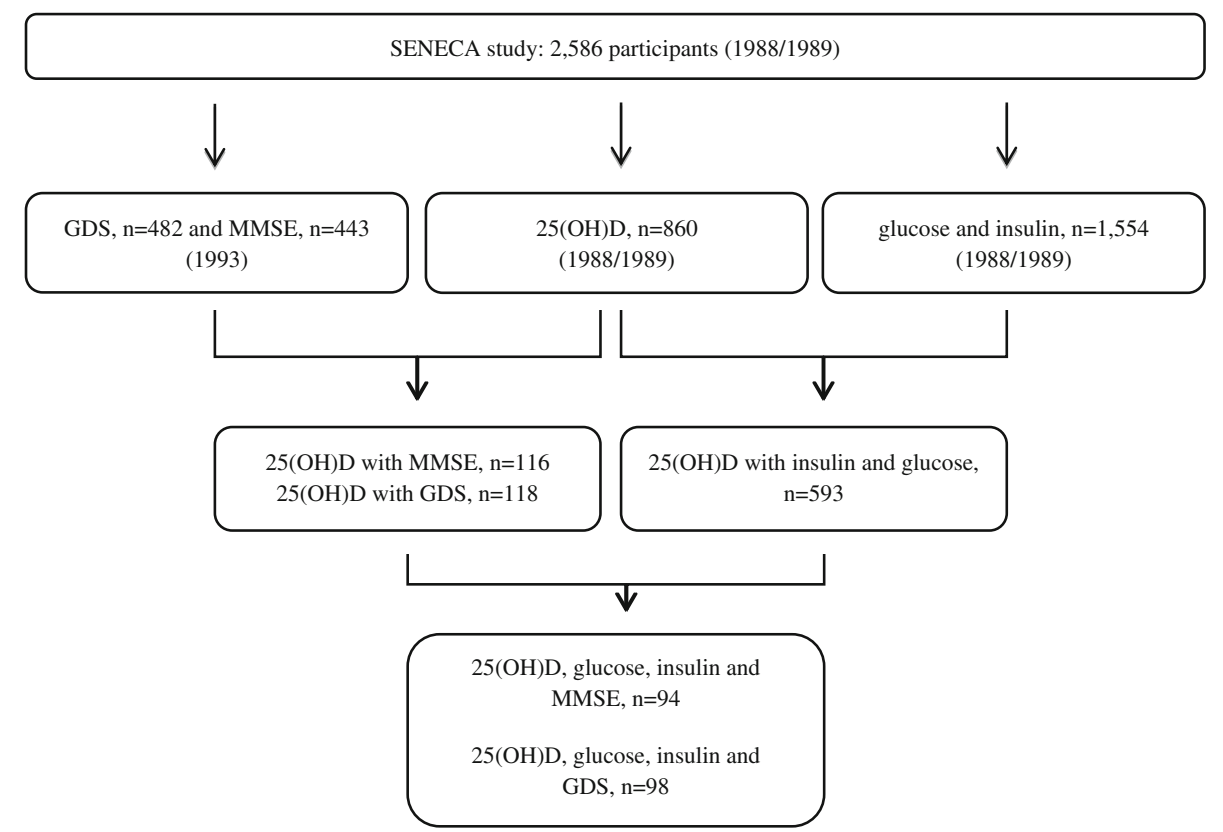

habitual physical activity [33]. Subjects were divided into 3 groups according to sex-specific tertiles: low, moderate or high physical activity level. Dietary intake was assessed by trained dietitians using the dietary history method. The method consisted of a 3-day estimated record and a frequency checklist of foods, based on the meal pattern of the country and with the previous month as a reference period. Portion sizes were checked by weighing quantities of food and household measures. Intakes of nutrients and food groups were calculated in each country using local food composition tables. Food consumption data were arranged into food groups following the EUROCODE classification system [34].

\section{Statistical analyses}

Population characteristics are reported as mean with standard deviation (SD) or percentages. Medians with interquartile range were used to report skewed variables. Chi-squared tests for categorical variables and one-way analysis of variance for continuous variables were performed to compare baseline characteristics over tertiles of 25(OH)D. Multiple regression analyses were performed to study the associations between $25(\mathrm{OH}) \mathrm{D}$ and fasting plasma glucose (FPG), fasting plasma insulin (FPI) and HOMA-IR as markers of insulin resistance. FPG, FPI and HOMA-IR were not normally distributed and therefore logarithmically transformed. $\beta$ 's are presented as $\%$ with $95 \%$ CI per $1 \mathrm{nmol} / \mathrm{L}$ increase in $25(\mathrm{OH}) \mathrm{D}$ (Table 3). As both mental health variables followed a Poisson distribution, rate ratios (RRs) for $25(\mathrm{OH}) \mathrm{D}$ with global cognitive performance [35] and depression were calculated using multiple Poisson regression with the number of erroneous answers as outcome for global cognitive functioning and the number of depressive symptoms as an outcome for depression. Participants were categorized according to tertiles of $25(\mathrm{OH}) \mathrm{D}$, using the lowest tertile as the reference category. In addition, a P- for trend across tertiles of 25(OH)D was calculated. All analyses were adjusted for age, sex (model 1), BMI, education, smoking, alcohol consumption, physical activity, study centre (model 2) and intake of calcium (model 3). To control for total energy intake, calcium intake was adjusted for total energy intake by using the regression residual method. The analyses were performed using the statistical package SAS, version 9.1 (SAS Institute Inc., Cary, NC, USA).

\section{Results}

General characteristics of the study population are presented in Tables 1 and 2. The mean \pm SD 25(OH)D level of the total population was $37.8 \pm 20.6$ and ranged from 6 to $141 \mathrm{nmol} / \mathrm{L}$. Serum $25(\mathrm{OH}) \mathrm{D}$ levels below $50 \mathrm{nmol} / \mathrm{L}$ and below $75 \mathrm{nmol} / \mathrm{L}$ were observed in $79 \%$ and $94 \%$ of the participants, respectively. Participants living in the southern part of Europe were more likely to have a suboptimal 25(OH)D level than those living in northern countries (data not shown). Those with the highest 25(OH)D levels were more likely to be men $(P=0.02)$, older $(P<0.0001)$ and higher educated $(P=0.001)$. Moreover, BMI $(P=0.07)$, FPG $(P=0.04)$, FPI $(P=$ $0.06)$ and HOMA-IR $(P=0.05)$ were lower, and physical activity levels $(P=0.0005)$ and total cholesterol concentrations $(P=0.001)$ were higher among those with the highest serum vitamin D levels. Thirty-two per cent of the 
Table 1 Characteristics of 593 elderly European men and women of the SENECA study per tertile of serum 25(OH)D

\begin{tabular}{|c|c|c|c|c|}
\hline & T1 (6-27 nmol/L) & $\mathrm{T} 2(28-42 \mathrm{nmol} / \mathrm{L})$ & T3 (43-141 nmol/L) & $P$ value \\
\hline$N$ & 204 & 196 & 193 & \\
\hline $25(\mathrm{OH}) \mathrm{D}(\mathrm{nmol} / \mathrm{L})$ & $19.2 \pm 5.3$ & $34.3 \pm 4.1$ & $61.0 \pm 18.3$ & $<0.0001$ \\
\hline Men, $n(\%)$ & $86(42)$ & $98(50)$ & $108(56)$ & 0.02 \\
\hline Age & $74.9 \pm 1.4$ & $74.6 \pm 1.5$ & $74.2 \pm 1.6$ & $<0.0001$ \\
\hline Body mass index ${ }^{a}$ & $27.4 \pm 4.4$ & $26.8 \pm 4.1$ & $26.5 \pm 3.4$ & 0.07 \\
\hline Fasting plasma glucose $(\mathrm{mmol} / \mathrm{L})$ & $6.2 \pm 1.9$ & $6.1 \pm 1.6$ & $5.8 \pm 1.5$ & 0.04 \\
\hline Fasting plasma insulin $(\mathrm{pmol} / \mathrm{L})$ & $67.9(46.8)$ & $74.5(61.3)$ & $62.4(43.4)$ & 0.06 \\
\hline HOMA-IR & $1.31(0.91)$ & $1.45(1.17)$ & $1.21(0.88)$ & 0.05 \\
\hline Chronic disease present, $n(\%)^{\mathrm{b}}$ & $166(81)$ & $158(81)$ & $144(75)$ & 0.24 \\
\hline Total cholesterol (mmol/L) & $6.2 \pm 1.2$ & $6.5 \pm 1.3$ & $6.7 \pm 1.1$ & 0.001 \\
\hline Hypertension, $n(\%)$ & $49(24)$ & $42(21)$ & $30(16)$ & 0.23 \\
\hline Stroke, $n(\%)$ & $5(2)$ & $13(7)$ & $11(6)$ & 0.10 \\
\hline \multicolumn{5}{|l|}{ Smoking status, $n \quad(\%)$} \\
\hline Non-smoking & $122(60)$ & $106(54)$ & $100(52)$ & 0.16 \\
\hline Current smoker & 39 (19) & $33(17)$ & $31(16)$ & \\
\hline Former smoker & $43(21)$ & $57(29)$ & $62(32)$ & \\
\hline \multicolumn{5}{|l|}{ Physical activity level, $n(\%)$} \\
\hline Low & $44(22)$ & $30(15)$ & $16(8)$ & 0.0005 \\
\hline Average & $74(36)$ & $67(34)$ & $58(30)$ & \\
\hline High & $86(42)$ & $99(51)$ & $119(62)$ & \\
\hline \multicolumn{5}{|l|}{ Educational level, $n(\%)$} \\
\hline Primary education & $122(60)$ & $110(56)$ & $102(53)$ & 0.001 \\
\hline Secondary education & $48(23)$ & $64(33)$ & $54(28)$ & \\
\hline Higher education & $14(7)$ & $9(4)$ & $29(15)$ & \\
\hline Illiterate & $20(10)$ & $13(7)$ & $8(4)$ & \\
\hline Calcium intake $(\mathrm{mg} / \text { day })^{\mathrm{a}}$ & $960 \pm 433$ & $998 \pm 424$ & $1,021 \pm 358$ & 0.33 \\
\hline Alcohol intake $(\mathrm{g} / \text { day })^{\mathrm{a}}$ & $0(10)$ & $2(13)$ & $1(9)$ & 0.17 \\
\hline
\end{tabular}

Values are expressed as a mean $\pm \mathrm{SD}$, median with IQR or $n(\%) . P$ value for $\chi^{2}$ test for categorical variables and one-way analysis of variance for continuous variables

a 12 missing values

${ }^{b}$ Presence of chronic disease was defined as hypertension, ischaemic heart disease, stroke, malignancy, arthritis/arthrosis, inflammatory bowel disease, respiratory problems, chronic liver disease, osteoporosis, Parkinson, others

participants had FPG levels, which exceeded $6.0 \mathrm{mmol} / \mathrm{L}$. Mean MMSE and median GDS scores of the population were $27.4 \pm 2.0$ and 2.0 (IQR 3.0), respectively. As the maximum score on the MMSE and GDS is, respectively, 30 and 15, these results indicate a low prevalence of mild cognitive impairment or depressive symptoms. When compared with the total sample, persons in the mental health subsample were somewhat younger, had a lower prevalence of chronic disease and moreover parameters of glucose metabolism were slightly lower.

Table 3 presents the decline in FPG, FPI and HOMA-IR in percentages per $1 \mathrm{nmol} / \mathrm{L}$ increase in $25(\mathrm{OH}) \mathrm{D}$. An inverse association was observed between $25(\mathrm{OH}) \mathrm{D}$ and FPG $(-0.1 \%, 95 \% \mathrm{CI}:-0.2,0.0)$, indicating a $1 \%$ decrease in FPG per $10 \mathrm{nmol} / \mathrm{L}$ increase in $25(\mathrm{OH}) \mathrm{D}$; however, after adjustment for demographic factors, lifestyle factors and calcium intake, this association was not statistically significant $(P=0.07)$. Significant inverse associations were also found for $25(\mathrm{OH}) \mathrm{D}$ with FPI and HOMA-IR, but these were attenuated after adjustment for covariates. Stratified analysis for calcium intake demonstrated a stronger association for $25(\mathrm{OH}) \mathrm{D}$ with FPG for those with a high calcium intake $(-0.2 \%, 95 \% \mathrm{CI}:-0.3$, $0.0)$, compared to those with a low intake $(0.0 \%, 95 \% \mathrm{CI}$ : $-0.2,0.1$ ) (data not shown in table). The interaction term, however, was not statistically significant, $P=0.38$ (data not shown in table).

Data on serum 25(OH)D levels and depression were available of 118 participants (Table 4). Fully adjusted models showed that compared to the reference group, those 
Table 2 Mental health characteristics of 135 elderly European men and women of the SENECA study per tertile of serum $25(\mathrm{OH}) \mathrm{D}$

\begin{tabular}{|c|c|c|c|c|}
\hline & $\mathrm{T} 1(7-33 \mathrm{nmol} / \mathrm{L})$ & $\mathrm{T} 2(34-52 \mathrm{nmol} / \mathrm{L})$ & T3 (53-125 nmol/L) & $P$ value \\
\hline$N$ & 50 & 43 & 42 & \\
\hline Age & $73.8 \pm 1.8$ & $73.7 \pm 1.7$ & $73.2 \pm 1.6$ & 0.06 \\
\hline MMSE score ${ }^{\mathrm{a}}$ & $27.3 \pm 2.1$ & $26.8 \pm 2.1$ & $27.9 \pm 1.9$ & 0.06 \\
\hline GDS score ${ }^{b}$ & $2.0(3.0)$ & $2.0(2.5)$ & $2.0(2.0)$ & 0.32 \\
\hline Fasting plasma glucose $(\mathrm{mmol} / \mathrm{L})^{\mathrm{c}}$ & $5.7 \pm 0.9$ & $6.1 \pm 2.1$ & $5.7 \pm 1.3$ & 0.43 \\
\hline Fasting plasma insulin $(\mathrm{pmol} / \mathrm{L})^{\mathrm{c}}$ & $63.8(46.3)$ & $64.8(57.4)$ & $48.6(44.3)$ & 0.84 \\
\hline HOMA-IR ${ }^{c}$ & $1.17(0.88)$ & $1.22(1.01)$ & $0.93(0.89)$ & 0.76 \\
\hline Chronic disease present, $n(\%)^{\mathrm{e}}$ & $34(77)$ & $26(68)$ & $28(67)$ & 0.54 \\
\hline Calcium intake $(\mathrm{mg} / \mathrm{day})^{\mathrm{d}}$ & $899 \pm 352$ & $934 \pm 325$ & $1,064 \pm 360$ & 0.07 \\
\hline
\end{tabular}

a 19 missing values

b 17 missing values

c 21 missing values

d 11 missing values

e Presence of chronic disease was defined as hypertension, ischaemic heart disease, stroke, malignancy, arthritis/arthrosis, inflammatory bowel disease, respiratory problems, chronic liver disease, osteoporosis, Parkinson, others

Table 3 Associations between 25(OH)D and markers of glucose metabolism of 593 men and women participating in the SENECA study, presented as \% with $95 \% \mathrm{CI}$ per $1 \mathrm{nmol} / \mathrm{L}$ increase in $25(\mathrm{OH}) \mathrm{D}$

\begin{tabular}{|c|c|c|c|c|c|c|}
\hline \multirow[b]{2}{*}{ Crude } & \multicolumn{2}{|c|}{ Fasting plasma glucose $(\mathrm{mmol} / \mathrm{L})$} & \multicolumn{2}{|c|}{ Fasting plasma insulin (pmol/L) } & \multicolumn{2}{|c|}{ HOMA-IR } \\
\hline & -0.1 & $-0.2,0^{\mathrm{e}}$ & -0.4 & $-0.7,0^{\mathrm{d}}$ & -0.4 & $-0.7,0$ \\
\hline Model $1^{\mathrm{a}}$ & -0.1 & $-0.2,0^{\mathrm{e}}$ & -0.3 & $-0.6,0.1$ & -0.3 & $-0.9,0.1$ \\
\hline Model $2^{\mathrm{b}}$ & -0.1 & $-0.2,0$ & -0.1 & $-0.4,0.3$ & -0.1 & $-0.5,0.3$ \\
\hline Model $3^{c}$ & -0.1 & $-0.2,0$ & -0.1 & $-0.4,0.3$ & -0.1 & $-0.5,0.3$ \\
\hline
\end{tabular}

a Adjusted for age and sex

b Adjusted for age, sex, BMI, education (categorical), alcohol intake (categorical), smoking (categorical), physical activity (categorical) and study centre (categorical)

c Adjusted for age, sex, BMI, education (categorical), alcohol intake (categorical), smoking (categorical), physical activity (categorical), study centre (categorical) and calcium intake (continuous)

${ }^{\mathrm{d}} P<0.05$

e $P \leq 0.01$

in the middle or upper tertile of $25(\mathrm{OH}) \mathrm{D}$ had on average a $27 \%$ (RR 0.73, $95 \%$ CI: 0.51-1.04) and $24 \%$ (RR 0.76, $95 \%$ CI: 0.52-1.11) ( $P$ for trend: 0.16) lower depression score, respectively. Additional adjustment for calcium intake (RR upper tertile 0.82 and $95 \%$ CI: 0.59-1.14), FPG (RR upper tertile 0.88 and $95 \%$ CI: 0.61-1.25) ( $n=83$, data not shown in table) or the prevalence of hypertension (RR upper tertile 0.82 and $95 \% \mathrm{CI}$ : 0.59-1.14, data not shown in table) did not alter the direction of the results.

Among 116 participants of whom 25(OH)D concentrations were known and the MMSE was completed (Table 4), age- and sex-adjusted models did not show significant associations for those in the middle or highest vitamin D group, RR 1.19 (95 \% CI: 0.86-1.63) and RR 0.76 (95 \% CI: 0.54-1.08), respectively. Further adjustment unexpectedly resulted in a statistically significant higher number of erroneous answers for those with intermediate vitamin D levels, RR 1.39 (95\% CI: 1.00-1.94). No such association was however observed for those with the highest vitamin D levels, RR 0.94 (95\% CI: 0.63-1.39). Associations did not substantially change when FPG levels, hypertension or depression were included in the model (RRs upper tertile 0.90 (95\% CI: 0.56-1.45), 1.03 (95 \% CI: 0.69-1.55) and 0.89 (95\% CI: 0.58-1.35), respectively, data not shown in table).

\section{Discussion}

In this cross-sectional population-based study among European elderly, participants with higher serum 25(OH)D concentrations tended to have less depressive symptoms. The data does not support the hypothesis that higher serum 
Table 4 Associations between 25(OH)D and mental health of 118 men and women participating in the SENECA study

\begin{tabular}{lllll}
\hline & $\mathrm{T} 1(0-34 \mathrm{nmol} / \mathrm{L})$ & $\mathrm{T} 2(34-52 \mathrm{nmol} / \mathrm{L})$ & $\mathrm{T} 3(52-125 \mathrm{nmol} / \mathrm{L})$ & $P$ for trend \\
\hline GDS (depression) & & & & \\
Crude model, $n=118$ & 1.0 & $0.78(0.53-1.14)$ & $0.76(0.50-1.15)$ & 0.05 \\
Model $1^{\mathrm{a}}, n=118$ & 1.0 & $0.80(0.55-1.16)$ & $0.76(0.49-1.17)$ & 0.05 \\
Model $2^{\mathrm{b}}, n=103$ & 1.0 & $0.73(0.51-1.04)$ & $0.82(0.59-1.14)$ & 0.16 \\
Model $3^{\mathrm{c}}, n=103$ & 1.0 & $0.74(0.53-1.06)$ & & 0.41 \\
MMSE (global cognitive functioning) & & $0.78(0.54-1.12)$ & 0.04 \\
Crude model, $n=116$ & 1.0 & $1.19(0.87-1.64)$ & $0.76(0.54-1.08)$ & 0.04 \\
Model $1^{\mathrm{a}}, n=116$ & 1.0 & $1.19(0.86-1.63)$ & $0.92(0.63-1.36)$ & 0.39 \\
Model 2 $2^{\mathrm{b}}, n=103$ & 1.0 & $1.42(1.02-1.97)^{\mathrm{d}}$ & $0.94(0.63-1.39)$ \\
Model 3 $3^{\mathrm{c}}, n=103$ & 1.0 & $1.39(1.00-1.94)^{\mathrm{d}}$ & 0.51 \\
\hline
\end{tabular}

${ }^{a}$ Adjusted for age and sex

b Adjusted for age, sex, BMI, education (categorical), smoking (categorical), physical activity (categorical), alcohol intake (categorical) and study centre (categorical)

c Adjusted for age, sex, BMI, education (categorical), smoking (categorical), physical activity (categorical), alcohol intake (categorical), study centre (categorical) and calcium intake (continuous)

${ }^{\mathrm{d}} P \leq 0.05$

vitamin $\mathrm{D}$ levels are associated with a better cognitive performance. Moreover, despite a modest inverse association between $25(\mathrm{OH}) \mathrm{D}$ and fasting plasma glucose, the hypothesized independent health benefits of $25(\mathrm{OH}) \mathrm{D}$ on insulin resistance could not be confirmed in this study.

Before interpreting the results, several methodological issues warrant further discussion. First of all, blood samples were collected during the winter season and therefore reflect the lowest $25(\mathrm{OH}) \mathrm{D}$ concentrations throughout the year. Secondly, serum $25(\mathrm{OH}) \mathrm{D}$ was measured only once and may therefore not reflect long-term status. Furthermore, the debate on the most accurate method to determine serum 25(OH)D levels is still ongoing [36], but the competitive protein-binding $(\mathrm{CPB})$ assay applied in this study might not be the most optimal method. A previous study comparing different serum $25(\mathrm{OH}) \mathrm{D}$ assays showed that CPB assay was highly correlated with radioimmunoassay (RIA) $(r=0.72)$ and high-performance liquid chromatography (HPLC) $(r=0.69)$. Additionally, mean 25(OH)D levels as measured with CPB assay appeared to be systematically higher compared to HPLC and RIA [37]. The $\mathrm{CPB}$ assay used in our study may therefore have resulted in an overestimation of the true $25(\mathrm{OH}) \mathrm{D}$ status. However, since it concerns a systematic overestimation, it will not have affected the strength or the direction of the observed associations. A strength of this study is that $25(\mathrm{OH}) \mathrm{D}$ samples were taken in ten countries all over Europe, collected during the same month and analysed in one single laboratory. Therefore, seasonal variation or inter-laboratory variation cannot have affected the results. Another strength of the SENECA database is that it includes extensive information on lifestyle and dietary factors including physical activity level and calcium intake, reducing the possibility of confounding significantly. Residual confounding by potential covariates as $\mathrm{PTH}$, however, cannot be ruled out.

Descriptive analyses showed lower 25(OH)D levels among those with a higher BMI, lower physical activity level and persons at older age. It may be suggested that in our population, those with a higher physical activity level performed part of their exercises outdoors, which may have resulted in higher $25(\mathrm{OH}) \mathrm{D}$ levels. The decrease in 25(OH)D with age may be explained by the fact that the production of vitamin $\mathrm{D}$ in the skin decreases while ageing [38]. Lower 25(OH)D levels among persons with a higher BMI have also been observed in previous studies and have been suggested to be the consequence of the storage of $25(\mathrm{OH}) \mathrm{D}$ in fat tissue and thus not being bioavailable in serum [39].

Among individuals in the SENECA study, FPG decreased with $1 \%$ when $25(\mathrm{OH}) \mathrm{D}$ increased with $10 \mathrm{nmol} / \mathrm{L}$; however, this was not statistically significant after adjustment for multiple factors. No association was observed between 25(OH)D with FPI or HOMA-IR. Biological evidence that vitamin $\mathrm{D}$ may affect markers of glucose metabolism and the development of diabetes is increasing [4, 40]. Previous published cross-sectional studies show however inconsistent results [41-46]. Among 142 Dutch men aged $70-88$ years, $25(\mathrm{OH}) \mathrm{D}$ was inversely associated with the area under the curve for both glucose and insulin, which remained significant after adjustment for BMI, skinfold thickness, alcohol, smoking and physical activity [41]. High levels of $25(\mathrm{OH}) \mathrm{D}$ were furthermore positively associated with insulin sensitivity and inversely correlated with $\beta$-cell function in a population of 126 young adults who underwent a hyperglycaemic clamp 
experiment [44]. Moreover, inverse associations with measures of insulin resistance were observed among participants of the Framingham Heart Study [43] and NHANES III [46]. The LIPGENE study [45] and the Women's Health Initiative [42] were not able to confirm previous evidence for a possible link between $25(\mathrm{OH}) \mathrm{D}$ and glucose metabolism. A recently published systematic review and meta-analyses with data of 5 prospective cohort studies showed that persons with $25(\mathrm{OH}) \mathrm{D}$ levels higher than $62.5 \mathrm{nmol} / \mathrm{L}$ had a $43 \%$ lower risk of developing type 2 diabetes when compared to those with levels below $35 \mathrm{nmol} / \mathrm{L}$ [15]. Mitri and colleagues (2011) also summarized the results of RCTs in this field and concluded that these trials do not yet provide definite evidence for a beneficial role of vitamin D supplementation on glycemic outcomes [15].

Despite a small sample size, this cross-sectional study showed a modest non-significant association between $25(\mathrm{OH}) \mathrm{D}$ and depression. Up to now, only very few population-based studies examined the possible link between $25(\mathrm{OH}) \mathrm{D}$ and depressive symptoms, showing contradictory results. For instance, 1-year follow-up of 7,358 middleaged and elderly Americans diagnosed with a cardiovascular event, without previous depressive episode, showed that patients with a $25(\mathrm{OH}) \mathrm{D}$ level $>125 \mathrm{nmol} / \mathrm{L}$ were less often depressed compared to persons with $25(\mathrm{OH}) \mathrm{D}$ levels $\leq 37.5 \mathrm{nmol} / \mathrm{L}$, HR 2.70 (1.35-5.40) [7]. Physical activity, socio-economic status or BMI were however not included as covariates. At 6 year of follow-up, women participating in the InCHANTI Study with the lowest 25(OH)D levels reported significantly more depressive symptoms, compared to those in the highest tertile. It has to be mentioned that a relatively large number (42\%) of the women participating in this study reported to have a depressed mood [8]. Furthermore, significantly lower 25(OH)D levels were also observed among 1,282 Dutch middle-aged and elderly with minor and major depressive symptoms, compared to those without depressive symptoms [6]. No clear beneficial role for vitamin D in depression was observed in population-based studies among Chinese elderly and Japanese municipal officials aged 21-67 years [25-27]. In one of these studies among Chinese elderly, a significant association between $25(\mathrm{OH}) \mathrm{D}$ and depression was observed at baseline, but not after 4 years of follow-up. The incidence rate of depression at 4 years of follow-up was $4 \%$ and in addition only $6 \%$ of the men had $25(\mathrm{OH}) \mathrm{D}$ levels below $50 \mathrm{nmol} / \mathrm{L}$, which may perhaps partially explain the lack of the association observed after 4 years [25]. Inconsistencies between studies may also be the result of differences in the ascertainment and prevalence of depression, lack of adjustment for covariates and differences in geographical location. As persons with depressive symptoms may be less likely to go outside, associations between serum vitamin D and depression observed in cross-sectional studies may also be the result of reverse causation. By performing RCTs, the possibility of reverse causation can be eliminated. However, up to now, only very few trials studied the effect of vitamin D supplementation on mood or depression, showing conflicting findings [47-51].

While there was evidence of an inverse association between $25(\mathrm{OH}) \mathrm{D}$ and the number of depressive symptoms, no association was observed between $25(\mathrm{OH}) \mathrm{D}$ and the number of erroneous answers on the MMSE. Results of several small studies reviewed by Annweiler and colleagues [5], and more recent and larger community-based cohort studies show either no or a positive association between vitamin D and global cognitive performance [16, $18,21,23-25]$. In 1,766 persons $\geq 65$ years, low vitamin D levels appeared to increase the probability of experiencing cognitive impairment, particularly in men [21]. Results of the EPIDOS study point towards the same direction in a population of elderly women (OR 1.99, $95 \%$ CI: $1.13-3.52, P=0.02$ ), even after adjustment for iPTH, serum calcium and depression [16]. Prospective data of the InCHANTI Study revealed that non-demented vitamin $\mathrm{D}$ deficient $(<25 \mathrm{mmol} / \mathrm{L})$ men and women were $64 \%$ more likely to experience cognitive decline, compared to those in the sufficient group ( $\geq 75 \mathrm{mmol} / \mathrm{l}$ ) [23]. The MrOS study [24], NAME study [18] and Os study [25] did not observe an association between serum vitamin D and global cognitive function. Recently, the first RCT on vitamin $\mathrm{D}$ supplementation and cognitive functioning was published, which did not show an effect of a 6-week treatment with $125 \mu \mathrm{g}$ cholecalciferol on working memory, response inhibition or cognitive flexibility in young adults [47]. Despite the fact that we could adjust for a large number of important confounders, our sample size may not have been large enough to detect an association. Moreover, data on global cognitive functioning were collected 4 years following the baseline measurements, which may also have affected the association studied. Although serum vitamin D levels have been shown to decrease with age [52], 2-year follow-up data of 80 fragile elderly, with a mean age of 82.1 years, showed however only a $6 \mathrm{nmol} / \mathrm{L}$ decrease in $25(\mathrm{OH}) \mathrm{D}$ [53]. Therefore, we expect that only a subtle decrease in $25(\mathrm{OH}) \mathrm{D}$ levels may have occurred during the period until the mental health indicators were measured.

In conclusion, this study showed a tendency towards an inverse association of $25(\mathrm{OH}) \mathrm{D}$ with FPG and depression but not with FPI, HOMA-IR and not with global cognitive performance. As the overall evidence for a role of vitamin $\mathrm{D}$ in glucose metabolism and mental health is still inconclusive, more prospective epidemiological studies, metaanalysis, randomized controlled trials and mechanistic studies are warranted. 
Acknowledgments This study was part of the EU/SENECA study on Nutrition and Health of the Elderly in Europe. The authors thank all principal investigators and collaborators of the SENECA study. Research presented in this article was financially supported by the Graduate School VLAG.

Conflict of interest The authors declare that they have no conflict of interest.

Open Access This article is distributed under the terms of the Creative Commons Attribution License which permits any use, distribution, and reproduction in any medium, provided the original author(s) and the source are credited.

\section{References}

1. Danaei G, Finucane MM, Lu Y, Singh GM, Cowan MJ, Paciorek CJ, Lin JK, Farzadfar F, Khang YH, Stevens GA, Rao M, Ali MK, Riley LM, Robinson CA, Ezzati M (2011) National, regional, and global trends in fasting plasma glucose and diabetes prevalence since 1980: systematic analysis of health examination surveys and epidemiological studies with 370 country-years and 2.7 million participants. Lancet 378:31-40

2. Biessels GJ, Staekenborg S, Brunner E, Brayne C, Scheltens P (2006) Risk of dementia in diabetes mellitus: a systematic review. Lancet Neurol 5:64-74

3. Anderson RJ, Freedland KE, Clouse RE, Lustman PJ (2001) The prevalence of comorbid depression in adults with diabetes: a meta-analysis. Diabetes Care 24:1069-1078

4. Alvarez JA, Ashraf A (2010) Role of vitamin d in insulin secretion and insulin sensitivity for glucose homeostasis. Int $\mathbf{J}$ Endocrinol 2010:351385

5. Annweiler C, Allali G, Allain P, Bridenbaugh S, Schott AM, Kressig RW, Beauchet O (2009) Vitamin D and cognitive performance in adults: a systematic review. Eur $\mathrm{J}$ Neurol 16:1083-1089

6. Hoogendijk WJ, Lips P, Dik MG, Deeg DJ, Beekman AT, Penninx BW (2008) Depression is associated with decreased 25-hydroxyvitamin D and increased parathyroid hormone levels in older adults. Arch Gen Psychiatr 65:508-512

7. May HT, Bair TL, Lappe DL, Anderson JL, Horne BD, Carlquist JF, Muhlestein JB (2010) Association of vitamin D levels with incident depression among a general cardiovascular population. Am Heart J 159:1037-1043

8. Milaneschi Y, Shardell M, Corsi AM, Vazzana R, Bandinelli S, Guralnik JM, Ferrucci L (2010) Serum 25-hydroxyvitamin D and depressive symptoms in older women and men. J Clin Endocrinol Metab 95:3225-3233

9. Martins D, Wolf M, Pan D, Zadshir A, Tareen N, Thadhani R, Felsenfeld A, Levine B, Mehrotra R, Norris K (2007) Prevalence of cardiovascular risk factors and the serum levels of 25-hydroxyvitamin D in the United States: data from the third national health and nutrition examination survey. Arch Intern Med 167:1159-1165

10. Jarrett RJ, Murrells TJ, Shipley MJ, Hall T (1984) Screening blood glucose values: effects of season and time of day. Diabetologia 27:574-577

11. Johnson JA, Grande JP, Roche PC, Kumar R (1994) Immunohistochemical localization of the $1,25(\mathrm{OH}) 2 \mathrm{D} 3$ receptor and calbindin D28 $\mathrm{k}$ in human and rat pancreas. Am J Physiol 267:E356-E360

12. Bland R, Markovic D, Hills CE, Hughes SV, Chan SL, Squires PE, Hewison M (2004) Expression of 25-hydroxyvitamin
D3-1alpha-hydroxylase in pancreatic islets. J Steroid Biochem Mol Biol 89-90:121-125

13. Maestro B, Campion J, Davila N, Calle C (2000) Stimulation by 1,25-dihydroxyvitamin D3 of insulin receptor expression and insulin responsiveness for glucose transport in U-937 human promonocytic cells. Endocr J 47:383-391

14. Eyles DW, Smith S, Kinobe R, Hewison M, McGrath JJ (2005) Distribution of the vitamin D receptor and 1 alpha-hydroxylase in human brain. J Chem Neuroanat 29:21-30

15. Mitri J, Muraru MD, Pittas AG (2011) Vitamin D and type 2 diabetes: a systematic review. Eur J Clin Nutr 65:1005-1015

16. Annweiler C, Schott AM, Allali G, Bridenbaugh SA, Kressig RW, Allain P, Herrmann FR, Beauchet O (2010) Association of vitamin $\mathrm{D}$ deficiency with cognitive impairment in older women: cross-sectional study. Neurology 74:27-32

17. Buell JS, Dawson-Hughes B, Scott TM, Weiner DE, Dallal GE, Qui WQ, Bergethon P, Rosenberg IH, Folstein MF, Patz S, Bhadelia RA, Tucker KL (2010) 25-Hydroxyvitamin D, dementia, and cerebrovascular pathology in elders receiving home services. Neurology 74:18-26

18. Buell JS, Scott TM, Dawson-Hughes B, Dallal GE, Rosenberg IH, Folstein MF, Tucker KL (2009) Vitamin D is associated with cognitive function in elders receiving home health services. J Gerontol A Biol Sci Med Sci 64:888-895

19. Lee DM, Tajar A, Ulubaev A, Pendleton N, O'Neill TW, O'Connor DB, Bartfai G, Boonen S, Bouillon R, Casanueva FF, Finn JD, Forti G, Giwercman A, Han TS, Huhtaniemi IT, Kula K, Lean ME, Punab M, Silman AJ, Vanderschueren D, Wu FC (2009) Association between 25-hydroxyvitamin D levels and cognitive performance in middle-aged and older European men. J Neurol Neurosurg Psychiatr 80:722-729

20. Llewellyn DJ, Lang IA, Langa KM, Melzer D (2010) Vitamin D and cognitive impairment in the elderly US population. J Gerontol A Biol Sci Med Sci 66:59-65

21. Llewellyn DJ, Langa KM, Lang IA (2009) Serum 25-hydroxyvitamin D concentration and cognitive impairment. J Geriatr Psychiatr Neurol 22:188-195

22. McGrath J, Scragg R, Chant D, Eyles D, Burne T, Obradovic D (2007) No association between serum 25-hydroxyvitamin D3 level and performance on psychometric tests in NHANES III. Neuroepidemiology 29:49-54

23. Llewellyn DJ, Lang IA, Langa KM, Muniz-Terrera G, Phillips CL, Cherubini A, Ferrucci L, Melzer D (2010) Vitamin D and risk of cognitive decline in elderly persons. Arch Intern Med 170:1135-1141

24. Slinin Y, Paudel ML, Taylor BC, Fink HA, Ishani A, Canales MT, Yaffe K, Barrett-Connor E, Orwoll ES, Shikany JM, Leblanc ES, Cauley JA, Ensrud KE (2010) 25-Hydroxyvitamin D levels and cognitive performance and decline in elderly men. Neurology 74:33-41

25. Chan R, Chan D, Woo J, Ohlsson C, Mellstrom D, Kwok T, Leung P (2011) Association between serum 25-hydroxyvitamin $\mathrm{D}$ and psychological health in older Chinese men in a cohort study. J Affect Disord 130:251-259

26. Nanri A, Mizoue T, Matsushita Y, Poudel-Tandukar K, Sato M, Ohta M, Mishima N (2009) Association between serum 25-hydroxyvitamin D and depressive symptoms in Japanese: analysis by survey season. Eur J Clin Nutr 63:1444-1447

27. Pan A, Lu L, Franco OH, Yu Z, Li H, Lin X (2009) Association between depressive symptoms and 25-hydroxyvitamin $\mathrm{D}$ in middle-aged and elderly Chinese. J Affect Disord 118:240243

28. Wilkins CH, Sheline YI, Roe CM, Birge SJ, Morris JC (2006) Vitamin D deficiency is associated with low mood and worse cognitive performance in older adults. Am J Geriatr Psychiatr 14:1032-1040 
29. Hof MA, Hautvast JG, Schroll M, Vlachonikolis IG (1991) Design, methods and participation Euronut SENECA investigators. Eur J Clin Nutr 453(Suppl):5-22

30. Mitchell AJ (2009) A meta-analysis of the accuracy of the minimental state examination in the detection of dementia and mild cognitive impairment. J Psychiatr Res 43:411-431

31. Almeida OP, Almeida SA (1999) Short versions of the geriatric depression scale: a study of their validity for the diagnosis of a major depressive episode according to ICD-10 and DSM-IV. Int J Geriatr Psychiatr 14:858-865

32. Matthews DR, Hosker JP, Rudenski AS, Naylor BA, Treacher DF, Turner RC (1985) Homeostasis model assessment: insulin resistance and beta-cell function from fasting plasma glucose and insulin concentrations in man. Diabetologia 28:412-419

33. Voorrips LE, Ravelli AC, Dongelmans PC, Deurenberg P, Van Staveren WA (1991) A physical activity questionnaire for the elderly. Med Sci Sports Exerc 23:974-979

34. Arab L, Wittler M, Schettler G (1987) European food composition tables in translation. Springer, Berlin

35. Kalmijn S, Feskens EJ, Launer LJ, Stijnen T, Kromhout D (1995) Glucose intolerance, hyperinsulinemia and cognitive function in a general population of elderly men. Diabetologia 38:1096-1102

36. Wallace AM, Gibson S, de la Hunty A, Lamberg-Allardt C, Ashwell M (2010) Measurement of 25-hydroxyvitamin D in the clinical laboratory: current procedures, performance characteristics and limitations. Steroids 75:477-488

37. Lips P, Chapuy MC, Dawson-Hughes B, Pols HA, Holick MF (1999) An international comparison of serum 25-hydroxyvitamin D measurements. Osteoporosis international: a journal established as result of cooperation between the European Foundation for Osteoporosis and the National Osteoporosis Foundation of the USA 9:394-397

38. Holick MF (1995) Environmental factors that influence the cutaneous production of vitamin D. Am J Clin Nutr 61:638S$645 \mathrm{~S}$

39. Wortsman J, Matsuoka LY, Chen TC, Lu Z, Holick MF (2000) Decreased bioavailability of vitamin D in obesity. Am J Clin Nutr 72:690-693

40. Pittas AG, Lau J, Hu FB, Dawson-Hughes B (2007) The role of vitamin $\mathrm{D}$ and calcium in type 2 diabetes. A systematic review and meta-analysis. J Clin Endocrinol Metab 92:2017-2029

41. Baynes KC, Boucher BJ, Feskens EJ, Kromhout D (1997) Vitamin $\mathrm{D}$, glucose tolerance and insulinemia in elderly men. Diabetologia 40:344-347

42. Chacko SA, Song Y, Manson JE, Van Horn L, Eaton C, Martin LW, McTiernan A, Curb JD, Wylie-Rosett J, Phillips LS,
Plodkowski RA, Liu S (2011) Serum 25-hydroxyvitamin D concentrations in relation to cardiometabolic risk factors and metabolic syndrome in postmenopausal women. Am J Clin Nutr 94:209-217

43. Cheng S, Massaro JM, Fox CS, Larson MG, Keyes MJ, McCabe EL, Robins SJ, O'Donnell CJ, Hoffmann U, Jacques PF, Booth SL, Vasan RS, Wolf M, Wang TJ (2010) Adiposity, cardiometabolic risk, and vitamin D status: the Framingham Heart Study. Diabetes 59:242-248

44. Chiu KC, Chu A, Go VL, Saad MF (2004) Hypovitaminosis D is associated with insulin resistance and beta cell dysfunction. Am J Clin Nutr 79:820-825

45. Gulseth HL, Gjelstad IM, Tierney AC, Lovegrove JA, Defoort C, Blaak EE, Lopez-Miranda J, Kiec-Wilk B, Riserus U, Roche HM, Drevon CA, Birkeland KI (2010) Serum vitamin D concentration does not predict insulin action or secretion in European subjects with the metabolic syndrome. Diabetes Care 33:923-925

46. Scragg R, Sowers M, Bell C (2004) Serum 25-hydroxyvitamin D, diabetes, and ethnicity in the third national health and nutrition examination survey. Diabetes Care 27:2813-2818

47. Dean AJ, Bellgrove MA, Hall T, Phan WM, Eyles DW, Kvaskoff D, McGrath JJ (2011) Effects of vitamin D supplementation on cognitive and emotional functioning in young adults-a randomised controlled trial. PLoS One 6:e25966

48. Dumville JC, Miles JN, Porthouse J, Cockayne S, Saxon L, King C (2006) Can vitamin D supplementation prevent winter-time blues? A randomised trial among older women. J Nutr Health Aging 10:151-153

49. Harris S, Dawson-Hughes B (1993) Seasonal mood changes in 250 normal women. Psychiatr Res 49:77-87

50. Jorde R, Sneve M, Figenschau Y, Svartberg J, Waterloo K (2008) Effects of vitamin D supplementation on symptoms of depression in overweight and obese subjects: randomized double blind trial. J Intern Med 264:599-609

51. Lansdowne AT, Provost SC (1998) Vitamin D3 enhances mood in healthy subjects during winter. Psychopharmacology 135:319-323

52. Chonchol M, Scragg R (2007) 25-Hydroxyvitamin D, insulin resistance, and kidney function in the third national health and nutrition examination survey. Kidney Int 71:134-139

53. Nakamura K, Nishiwaki T, Ueno K, Yamamoto M (2007) Agerelated decrease in serum 25 -hydroxyvitamin $\mathrm{D}$ concentrations in the frail elderly: a longitudinal study. J Bone Miner Metab 25:232-236 